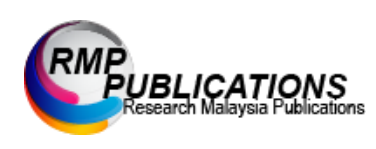

Journal of Social Science and Humanities, 4 (2): 06-13, 2021

e-ISSN: 2600 - 9056

(C) RMP Publications, 2021

DOI: $10.26666 / \mathrm{rmp} . j s s h .2021 .2 .2$

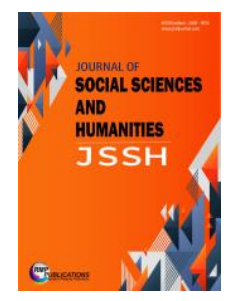

\title{
Anime and Social Disorders among Secondary School Adolescents
}

\author{
Nur Afian Yusof, Khairul Anwar Mastor, Hamdzun Haron, Aminudin Basir and Jamsari Alias \\ Pusat Citra Universiti, Universiti Kebangsaan Malaysia, 43600 Bangi, Selangor, Malaysia,
}

\begin{abstract}
Social problems among adolescents have been giving a huge impact on the formation of people in a community who live in the world of modern technology. Social problems are oftenly associated with fast-paced mass media that that come with information technology and sophistication. Anime is the entertainment brought by the electronic mass media for the children, youth and adults who have dominated the world of animation today. The difference in the characters, morals and cultures are believe to be a major for moral declination among teenagers. The elements of violence, sex, fantasy and superstition can be damage teenagers mind. A lot of anime studies show adversely and positive effects to the teenagers. Statistics from the Department of Statistics show the number of juvenile offenders in 2016 recorded a decline of $10.3 \%$ from 5,096 cases in 2014 to 4,569 cases in 2015. However, the number is not enough to release anxiety among the public on this issue. A pilot study was conducted on 85 respondents teenagers aged 13 and 16 years old by using quantitative methods. Results showed that there was positive effect on the result of watching anime, while the remainder showed there was no significant relationship to the social problems on this
\end{abstract}

\section{Key words: Anime, Social Disorders, Adolescents, Secondary School}

\section{INTRODUCTION}

Social issues caused by the crises of moral degradation due to the extreme and widespread proliferation of borderless mass media is a plague that concerns our society today. We often see and hear news of social issues through news in newspapers and television. To worsen the situation, this issue involves adolescents who are the country's future human capital.

The lives of adolescents today who are exposed to a variety of unfiltered external information and cultures brought by mass media can influence their minds and behaviours. Social ills such as free association, illegal racing, substance abuse, abortion, gambling, bullying, gangsterism and so forth are still at a frightening degree even while figures show a $15 \%$ decline in 2010. Statistics show that a total of 4,474 children as young as 7 years of age have been arrested for various criminal cases. A total of 135,121 criminal cases involving children, students and adolescents as a whole were also recorded in Bukit Aman statistics. The findings from these statistics are indeed alarming and disturbing. This was acknowledged by the Director General of Education, Datuk Abdul Ghafar Mahmud, when the Crime Prevention Club uniform was launched at national level in 2011. According to him, statistics released from Bukit Aman have shown an increase of $111 \%$ of criminal cases involving juvenile offenders within a year. A total of 7,816 cases were recorded in 2013 compared to 3,700 cases in 2012 which showed an increase of 4,116 cases. In addition to the alarming number of criminal activities involving adolescents who graduated from school, an increase of $137 \%$, which is 2,011 cases in 2013 compared to 849 cases in the previous year.

Serious crimes involving adolescents between 12 and 17 years of age have also seen an increase of up to $47 \%$ throughout the country and some were involved in murder and rape cases [1].

One of the statistics presented by Datuk Seri Ahmad Zahid Hamidi in the Parliamentary session was that 751 juvenile cases involving rape offenses were recorded in 2014, 674 cases in 2015 and 691 cases in 2016. In 2014, 2907 cases of violent crime were reported, followed by 2529 cases in 2015 and 2526 cases in 2016. Motorcycle theft cases recorded 3,110 cases involving teenagers aged seven to ten years old in 2014. In 2015, cases declined to 2,634 while in 2016 marginally rose to 2,655 . While cases involving property crimes were recorded at 6,386 in 2014, a 
decrease was seen in the number of cases to 5,605 in 2015 and further down to 5,459 in 2016.

Why do these social problems occur and what causes them to develop and become more serious? A number of scientific studies have been conducted to unroot the cause of this social ills issues. In general, these social disorders can be described as a situation or way of life in a society where they are contrary or contradictory to the characteristics or values of a culture and to the religious values of a society. According to, social disorder is seen as a human behavior that does not comply with ordinary boundaries which is generally accepted in both religion, society and culture. Social ills caused by the deterioration of traditional standards include not only adolescents and teenagers but also adults. As far as social ills among teenagers is concerned, however, several studies indicate that negative content, primarily in magazines and television, has been shown to be significant in terms of being relevant causes [2].

Anime is a Japanese film and TV animation style that has won fans all over the world including Malaysia. Anime entry into Malaysia began in the 1980 's on RTM with the Doraemon series which created a phenomenon for fans of animated series, particularly children and teenagers. This high demand has then brought many more Japanese animated series to the Malaysian television network. A variety of superhero characters, action, exciting graphic displays and unpredictable storylines are the charms of anime. According to Novianti [3], many people are enthusiastically embracing anime under the pretext of deepening the Japanese language and culture, but there are also issues of the influence of social disorders as a result of the emergence of anime.

The emergence of anime with negative features and a foreign culture that is contrary to local culture has not only concerned our Malaysian society, but also the global community as a whole. In early 2008 in Semarang, Indonesia, a 10-year-old child, Revino Siahaya died as a result of his alleged imitation of the actions of his favorite anime hero Naruto. Meanwhile in Russia, a 14-year-old teenager jumped from his apartment in Chaikovsky after his idol anime hero Itachi Uchiha was killed in the story [4]. Various studies on anime have been conducted and various negative and positive findings have been recorded. The fact is that despite the worrying issues, there are also positive findings related to anime. Among them, a study from Sameen [5] on anime is said to increase social interaction as well as cultivate interest in art and language among adolescents. However, it should not be excluded that excessive exposure to anime can cause teenagers to addictive watching, a cause to restrict other activities and can result problems of attitude and behavior. Eng [6] in his study found that teens who watch anime have been able to increase social interaction between them. Similarly, the findings of a study from Gaylican [7] who found that social interaction among adolescents increases and can transform a shy teenager into an extrovert individual. Various findings of research, whether positive or negative, should refer to detailed study data based on the subject and location of the study. Thus, this study was conducted to find out whether anime is also a contributor to one of the factors of social ills occurring in today's society, or is it merely a perception of prejudice.

\section{OBJECTIVE}

This study aims to meet the following objectives:

a) Identify the factors why teenagers favour anime.

b) Identify the frequency of anime watching among adolescents.

c) Identify the relationship between anime and social disorders among adolescents.

\section{LITERATURE REVIEW}

\section{Anime, Adolescents and Social Disorders}

Anime is taken from the English acronym 'animation' which is shortened to three syllables in Japanese which means animation derived from comics or manga in Japanese. According to Gravett manga is a comic created in Japan, or by Japanese creators in Japanese as well as adhering to the style developed in Japan in the late 19th century. In Japan, the general public reads manga that consists of various genres such as adventure, love, sports, drama, history, comedy, science fiction, fantasy, mystery, investigation, horror, sex, business and so on [8].

Since the 1950s, manga has become one of the leading publishing industries in Japan. In fact, it has grown and become popular all over the world. According to Gaylican [7] markets in Europe and the Middle East have recorded a profit of up to 250 million dollars, while the American market has recorded a figure of 120 million dollars until 2012. That is how popular Manga is all over the world. Anime is born from the popularity of Japanese Manga. According to the Merriam-Webster Dictionary, Anime is Japanese animation born from popular Manga stories developed and presented in animated form. Manga and Anime is an inseparable Japanese creative work. The only difference is that Manga in printed form, while Anime in the form of animation shown on television.

Now anime has become the favorite entertainment material for children and teenagers from all over the world, including our country. The screening 
of this anime series also brings foreign cultures, especially Japanese, to the minds of teenagers. The application of foreign culture that does not conform to and contrary to local cultural and religious values can instill negative values to adolescents who are exposed to it [9]. The strength of this anime series lies in the glory of its characters, such as Naruto, Goku, Doraemon, Sin Chan and many others, coupled with the esthetic presentation of the graphics illustrated. This makes the anime very attractive.

What is now becomes a concern is that the use of unlimited internet technology allows anime to be watched regardless of time and place, which also presents teenagers with different stories, storytelling and anime characters with unfiltered content. It is feared that the situation includes adverse elements which can impact on the morality and actions of youngsters and encourage them to participate in negative activities which lead to the growing number of disturbing social disorders. This boundless exposure and exploitation can jeopardize the perception and moral values of teenagers if it is not curbed in a study entitled "Why are Asians so responsive and available to enjoy Japanese Anime series?". It is associated with local TV shows that showcase Japanese animated series on children and teenagers's slots. What is worrying is that the content of Anime is not in keeping with moral values and local culture and can cause significant damage to the development of adolescents.

Chambers [10] also claimed that anime containing harmful elements such as violence is inappropriate for teenagers. Studies from Sallehuddin [11] also found that most children and teenagers enjoy anime because of its beautiful graphic visuals, elements of humor and violence embedded in the storytelling. However, anime with elements of extreme violence can also contribute to hostile attitudes and behaviour.

Other studies indicate, however, that anime exposure has a positive impact. Among them is a study by Jesus [12] which stated that adolescents who are exposed to anime may increase their aesthetic appreciation of art later in their adulthood. This opinion is also shared by Gaylican [7] that those who watch anime will be more interested in the field of art. While Eng [8] mentions that anime can enhance social interaction among adolescents and increase interest in Japanese culture and language. Sameen's [5] findings show that anime not only enables teenagers to appreciate art well but indirectly can increase their sense of creativity. According to Sameen, anime can help teenagers understand the difference between right and wrong and foster a responsible attitude towards their own actions as well as teach honesty, generosity and respect for others.
Notwithstanding the positive implications, anime also has a negative effect if watched excessively and will cause teenagers to become addicted and unable to concentrate on their learning as well as can damage attitudes and behaviours as a result of the elements of violence depicted. In addition, extreme anime exposure encourages teenagers to imitate the anime character who is their idol and fantasize about being the character. A 21-year-old adolescent, Amirul Rizwan Musa from Kelantan or better known as Miyyo Rizone has performed facial surgery to look like a character in the Final Fantasy anime. Such is the effect brought by the influence of anime on teenagers who are exposed to various positive and negative elements.

Adolescence is defined as a period of transition from childhood to adulthood and according to the United Nations (United Nations) adolescents are classified from the age of 15 to 24 years (Unesco.org). While Sameen [5] defines adolescents as those between the ages of 11 and 21 years of age, a transition between childhood and adulthood that involves biological, psychological, social and economic changes as well as immature to mature stages.

Psychologists argue that adolescence, according to Rastati [13] is a crucial period in adolescent self-development because of the challenges and stress they are experiencing. During this period, teenagers often want to attempt something that can sometimes trigger social and anti-social conflict in their actions. While according to Roosfa [9] adolescents are youth who have started to mature, have reached puberty, are old enough to marry, have developed a sense of lust and are no longer children, in other words, adolescents distinguish children from adults. Psychologists are therefore of the opinion that adolescents should be given the freedom to deepen and find life experiences that it is appropriate for their own development [12].

Social disorder refers to harmful behaviours in a society which are not helpful to the effectiveness of the system and the economic stability of the individual, a group or a nation [14]. There are many factors that motivate adolescents to participate in unhealthy social illness today. According to Hutabalian [15] the involvement of adolescents in various social illness stems from a number of factors, including the internal factors of adolescents themselves in terms of personality development, the failure of family institutions and the influence of peers. Zainal [16] argued that the influence of school environment is also a cause of social illnesses among adolescents. Other than that, the lack of religious education is the one of the factors in the occurrence of social disorder among adolescents [16]. This was agreed by Idris, F. et al. [17], where adequate religious education can prevent adolescents from engaging in 
social disorder. While Azmi [18], said, another factor that contributes to social disorder is the lack of parental supervision over the children which causes them to seek outside intentions.

While Tengku Elmi Azlina [19] attributed the internal factors and the development of personality of adolescents themselves to be a factor in the onset of social disorder if they do not get full guidance in facing the challenges of adolescence. Tamuri [2], later stated that the negative content found in mass media also contributes to the social illness of adolescents today. This opinion is supported by Sohana [20], mass media content that contains negative elements can affect social problems that occur in adolescents. Adverse effects resulting from negative elements in the mass media are also agreed by Abdullah [22]. Thus, the role of mass media in the social ills of adolescents today should not be taken lightly because the content of mass media is more easily disseminated in this era with the help of information technology without borders.

\section{METHODOLOGY}

This study uses a quantitative approach using a set of Likert 5 scale questionnaires that have been developed by researchers with reliability and validity values of 0.865 alpha cronbach on the Moral Misconduct instrument. This set of questionnaires was built to measure the anime's relationship to moral decay which leads to the problem of social illnesses among adolescents in the state of Selangor.

This set of questionnaires examines the level of anime exposure or viewing among adolescents as well as its relationship to moral misconduct consisting of 26 items in the breakdown of domains such as religion, life, reason and property that lead to social problems. The data collected will be analyzed using SPSS software and will be evaluated as primary data in this study.

\section{Research Instrument}

The research instrument used in this study to suit the objectives of the study. In total there are only 26 items have been used out of 49 items that include 4 domains namely religion, life, reason and property. This questionnaire contains 2 parts, namely Part A related to the demographics of the respondents and Part B is an instrument of moral misconduct (social illness).

An initial census of the anime most watched by teenagers was conducted at Bukit Changgang Secondary School involving 100 respondents consisting of 50 people aged 13 years and another 50 people aged 16 years. A total of 34 anime series have been delected to find the 5 anime series most watched by teenagers. Here is the census schedule:

\begin{tabular}{|c|c|c|}
\hline Anime & Total & Percentage \\
\hline Kiteretsu & 28 & 5.6 \\
\hline Detective Conan & 63 & 12.6 \\
\hline Chibi Maruko & 16 & 3.2 \\
\hline Muscleman & 4 & .8 \\
\hline Ninja Boy & 10 & 2.0 \\
\hline Doraemon & 60 & 12.0 \\
\hline Nonochan & 1 & .2 \\
\hline Cardfight!!! & 3 & .6 \\
\hline Ninja Hatori & 10 & 2.0 \\
\hline Inazuma Eleven & 16 & 3.2 \\
\hline $\begin{array}{l}\text { Full Metal } \\
\text { Alchemist }\end{array}$ & 12 & 2.4 \\
\hline Dragon Ball & 29 & 5.8 \\
\hline Dr. Slump Arale & 5 & 1.0 \\
\hline Stitch & 6 & 1.2 \\
\hline Chimpui & 1 & .2 \\
\hline Digimon Fusion & 5 & 1.0 \\
\hline Naruto & 51 & 10.2 \\
\hline Little Battlers & 2 & .4 \\
\hline Sket Dance & 3 & .6 \\
\hline Letter Bee & 1 & .2 \\
\hline Hunter X Hunter & 6 & 1.2 \\
\hline Keroro Season & 11 & 2.2 \\
\hline Ryukendo & 7 & 1.4 \\
\hline Scan2go & 3 & .6 \\
\hline Hagemaru & 32 & 6.4 \\
\hline One Peice & 32 & 6.4 \\
\hline Origami & 4 & .8 \\
\hline Crayon Shin Chan & 40 & 8.0 \\
\hline Beezlebub & 4 & .8 \\
\hline Fairy Tail & 27 & 5.4 \\
\hline Lucky Star & 2 & .4 \\
\hline Others & 6 & 1.2 \\
\hline Total & 500 & 100 \\
\hline
\end{tabular}

Table 1 Results of Anime Popularity Census

Respondents were asked to list the 10 most popular anime. As a result of the census, the top 5 anime receiving top placing were; 1. Detective Conan, 2. Doraemon, 3. Naruto, 4. Crayon Shin Chan and also 5. One Piece. Therefore, the anime exposure in this study is focused on these 5 series only and does not involve any other anime series.

\section{Scoring}

Figures This Likert model was chosen because of its reliability in data findings that can be determined easily and accurately and can reduce errors in data processing

For this study, the likert scale using the fivechoice consent system was used as shown in Table 2 below: 


\begin{tabular}{ll}
\hline Degree of Consent & Score \\
\hline Never & 1 \\
Rarely & 2 \\
Occasionally & 3 \\
Frequently & 4 \\
Constantly & 5 \\
\hline
\end{tabular}

Table 2 Degree of Likert Consent System

\section{Respondent}

This study was conducted on adolescents consisting of students of Bandar Baru Salak Tinggi Secondary School in Sepang, Selangor who are Muslims. Respondents are limited to the age range of 13 and 16 years only, form 1 and Form 4 consisting of male and female who are exposed to anime viewing. After the screening, only 85 respondents were involved with this questionnaire study. Filters were made in advance where students who were not exposed to anime did not participate in this study.

\section{RESEARCH FINDINGS}

\section{Demographics}

The following is a table related to the demographics of the respondents involved:

\begin{tabular}{|c|c|}
\hline Item & $\begin{array}{l}\text { Findings (Frequency / } \\
\text { Percentage) }\end{array}$ \\
\hline Gender & $\begin{array}{l}\text { Male }(49 / 57.6 \%) \\
\text { Female }(36 / 42.4 \%)\end{array}$ \\
\hline Age & $\begin{array}{l}13 \text { year old }(29 / 34.1 \%) \\
16 \text { year old }(56 / 65.9 \%)\end{array}$ \\
\hline Race & $\begin{array}{l}\text { Malay }(84 / 98.8 \%) \\
\text { Chinese }(1 / 1.2 \%)\end{array}$ \\
\hline Form & $\begin{array}{l}\text { One }(29 / 34.1 \%) \\
\text { Four }(56 / 65.9 \%)\end{array}$ \\
\hline $\begin{array}{l}\text { Father's } \\
\text { Occupation }\end{array}$ & $\begin{array}{l}\text { Public Sector }(34 / 40.0 \%) \\
\text { Private Sector }(32 / 37.6 \%) \\
\text { Self Employed }(19 / 22.4 \%)\end{array}$ \\
\hline $\begin{array}{l}\text { Mother's } \\
\text { Occupation }\end{array}$ & $\begin{array}{l}\text { Public Sector }(29 / 34.1 \%) \\
\text { Private Sector }(14 / 16.5 \%) \\
\text { Self Employed }(42 / 49.4 \%)\end{array}$ \\
\hline Family Income & $\begin{array}{l}\text { RM1000 and below }(11 / 12.9 \%) \\
\text { RM1000 - RM3000 (37 / 43.5\%) } \\
\text { RM3000 - RM5000 (26 / 30.6\%) } \\
\text { RM5000 and above }(11 / 12.9 \%)\end{array}$ \\
\hline
\end{tabular}

Table 3 Demographics of Respondents

Demographics from the study showed that the number of male respondents was higher than that of female respondents. This explains that male respondents watch anime more than female respondents, taking into consideration the pre-conditions of the study, which limit those respondents who watch and enjoy anime only. The data also shows that 16-year-old respondents are higher than 13-year-old respondents, and this data is similar to the findings on the educational level of the respondents. The majority of respondents, $98.8 \%$ are Malay and only $1.2 \%$ are Chinese. The majority of respondents are from the group that fathers work in the public sector, while the majority of respondents' mothers are self-employed or housewives. The total family income shows that the majority of household income is around RM1000-RM3000 per month.

\section{Respondent}

The reliability of the Moral Misconduct item as a whole out of 26 items is 0.865 cronbach's alpha value which indicates that this instrument is reliable. While Table 4 shows the mean distribution of the frequency of watching anime and moral misconduct which shows the data of both variables are at a low level.

\begin{tabular}{lll}
\hline & Alfa Cronbach & Number of items \\
\hline $\begin{array}{l}\text { Moral } \\
\text { misconduct }\end{array}$ & 0.865 & 26 \\
\hline
\end{tabular}

Table 4 Item Reliability

\begin{tabular}{llll}
\hline & Min & SP & Level \\
\hline $\begin{array}{l}\text { Frequency of anime } \\
\text { watching }\end{array}$ & 1.51 & 0.629 & Low \\
Moral misconduct & 1.41 & 0.301 & Low \\
\hline
\end{tabular}

Table 5 Mean Values and Standard Deviations

\section{Teen Factors Interested in Anime}

The Table 6 shows the findings of 3 factors why teenagers enjoy anime. The majority of respondents as many as $67.1 \%$ are fans of anime due to the character which portray as having magical powers, funny, cute and so on, while another $24.7 \%$ love anime because of its beautiful and attractive graphic visuals. Only $8.2 \%$ love anime because of its interesting and fascinating storyline. This finding supports the study of Roslina Mamat et.al [22] where adolescents are interested in anime because of the anime character factor itself which are courageous, hardworking, humour, appreciation for relationships and having special abilities. Meanwhile, the study found that the majority of teenagers are interested in anime because of the moral values found in anime, while the rest are factors such as interesting storyline, beautiful visuals and anime character persona. 
Hamdzun et. al// Journal of Social Science and Humanities, 4(2) 2021, Pages: 06-13

\begin{tabular}{lll}
\hline Factor & Number & Percentage \\
\hline $\begin{array}{l}\text { Anime charaters possessing } \\
\text { magical powers, humour, cute } \\
\text { and so on. }\end{array}$ & 57 & 67.1 \\
$\begin{array}{l}\text { Beautiful and attractive visula } \\
\text { graphic. }\end{array}$ & 21 & 24.7 \\
$\begin{array}{l}\text { Interesting and fascinating } \\
\text { storyline. }\end{array}$ & 7 & 8.2 \\
Total & $\mathbf{8 5}$ & $\mathbf{1 0 0 . 0}$ \\
\hline
\end{tabular}

Table 6. Teenagers Factors of Interest in Anime

Identifying the Frequency Level of Anime Viewing

Table 7 below shows the breakdown of the frequency of watching anime in a week for the 85 respondents involved in this study. The majority of $56.5 \%$ of respondents allocate 1 - 3 hours a week, while another $36.5 \%$ watch anime at the level of 3-5 hours a week and only a small percentage of $7.1 \%$ of respondents watch anime more than 5 hours a week. These findings indicate that the frequency of watching for the respondents in this study is at a low level. This can be referred to the majority of low viewing levels in Table 7 and the mean value of 1.51 in Table 5 .

\begin{tabular}{lll}
\hline Viewing Hours & Numbers & Percentage \\
\hline 1-3 hours & 48 & 56.5 \\
3-5 hours & 31 & 36.5 \\
5 hours and above & 6 & 7.1 \\
Total & $\mathbf{8 5}$ & $\mathbf{1 0 0 . 0}$ \\
\hline
\end{tabular}

Table 7 Frequency of Watching Anime in a Week

Table 9 shows the relationship between anime and 26 items of moral misconduct referring to the moral deterioration in this study. Pearson's correlation analysis was used to see the relationship or influence of anime viewing frequency with 26 items of moral misconduct. The following table of correlation criteria adopted by Guilford [23] is used to better understand the relationship:

\begin{tabular}{ll}
\hline Correlation Coefficient & Indicator \\
\hline$=0.20$ & Extremely weak relationship \\
$>0.20-0.40$ & Weak relationship \\
$>0.40-0.70$ & Plain relationship \\
$>0.70-0.90$ & Strong relationship \\
$>0.90$ & Extemely strong relationship \\
\hline & Source: Guilford, J.P $(1956)$
\end{tabular}

Table 8 Guilford Criteria (1956)

\begin{tabular}{|c|c|c|c|}
\hline No. & Moral Misconduct & $\begin{array}{l}\text { Correlation } \\
\text { coefficient }\end{array}$ & $P$ value \\
\hline \multicolumn{4}{|c|}{ Religious Domain } \\
\hline 1 & $\begin{array}{l}\text { Deliberately omitting the } \\
5 \text { prayer times }\end{array}$ & -0.154 & 0.160 \\
\hline 2 & $\begin{array}{l}\text { Deliberately do not fast } \\
\text { in the month of } \\
\text { Ramadhan }\end{array}$ & $-0.284 *$ & 0.008 \\
\hline 3 & $\begin{array}{l}\text { Disobidience towards } \\
\text { parents }\end{array}$ & $-0.225^{*}$ & 0.038 \\
\hline 4 & $\begin{array}{l}\text { Speak to elderly people } \\
\text { harshly }\end{array}$ & -0.129 & 0.238 \\
\hline 5 & $\begin{array}{l}\text { Estrangement between } \\
\text { family/relatives }\end{array}$ & -0.164 & 0.133 \\
\hline 6 & $\begin{array}{l}\text { Create conflict (to cause } \\
\text { disagreement which } \\
\text { would result in the } \\
\text { seperation of a } \\
\text { friendship, etc.) }\end{array}$ & -0.160 & 0.145 \\
\hline 7 & Shirk to Allah s.w.t. & -0.042 & 0.701 \\
\hline 8 & $\begin{array}{l}\text { Do not perform the full } \\
\text { ablution(full body } \\
\text { purification after } \\
\text { impurities) }\end{array}$ & -0.032 & 0.774 \\
\hline 9 & $\begin{array}{l}\text { Gossiping/Talk } \\
\text { maliciously about } \\
\text { someone }\end{array}$ & -0.063 & 0.566 \\
\hline 10 & Fault finding & -0.189 & 0.083 \\
\hline \multicolumn{4}{|c|}{ Life Domain } \\
\hline 11 & Smoking & 0.074 & 0.501 \\
\hline 12 & Illegal racing & -0.170 & 0.120 \\
\hline 13 & $\begin{array}{l}\text { Physical fight (Hitting, } \\
\text { kicking, etc.) }\end{array}$ & -0.071 & 0.520 \\
\hline 14 & $\begin{array}{l}\text { Gambling which led to a } \\
\text { fight }\end{array}$ & -0.002 & 0.988 \\
\hline 15 & Self-inflicted injury & -0.039 & 0.726 \\
\hline \multicolumn{4}{|c|}{ Reason Domain } \\
\hline 16 & Sniffing glue & -0.088 & 0.422 \\
\hline 17 & Extravagant spending & 0.075 & 0.494 \\
\hline 18 & $\begin{array}{l}\text { To be neglectful when } \\
\text { listening to music }\end{array}$ & -0.126 & 0.251 \\
\hline 19 & $\begin{array}{l}\text { Learn esoteric knowledge } \\
\text { but hides the knowledge }\end{array}$ & -0.067 & 0.543 \\
\hline \multicolumn{4}{|c|}{ Property Domain } \\
\hline 20 & $\begin{array}{l}\text { Steal the valuables of } \\
\text { others }\end{array}$ & -0.056 & 0.608 \\
\hline 21 & $\begin{array}{l}\text { Breaking and entering } \\
\text { someone's home }\end{array}$ & -0.001 & 0.989 \\
\hline 22 & $\begin{array}{l}\text { Vandalising self or } \\
\text { family's property }\end{array}$ & 0.047 & 0.669 \\
\hline 23 & Stealing from family & 0.035 & 0.752 \\
\hline 24 & $\begin{array}{l}\text { Cheating other people's } \\
\text { money }\end{array}$ & -0.025 & 0.819 \\
\hline 25 & $\begin{array}{l}\text { Wastage (food / } \\
\text { electricity etc.) }\end{array}$ & $-0.294 *$ & 0.006 \\
\hline 26 & $\begin{array}{l}\text { Vandalism of public } \\
\text { property }\end{array}$ & -0.088 & 0.423 \\
\hline
\end{tabular}

Table 9 The Association between Anime and Social Ills in Adolescents 
The data in table 8 above indicates Pearson 's association between religion, life, reason and property, which is divided into 4 principal domains. There are 2 items with a major relationship with the religious sphere, while the other items in the religious sector are insignificant. "Deliberately do not fast in the month of Ramadhan" and "disobedience towards parents" has a negative correlation with the frequency of watching anime. This shows that the more often teenagers watch anime, they will not deliberately leave fasting in the month of Ramadan, as well as disobeying parents. However, this association is at a low point, according to Guilford (1956) guidelines. But this explains that there is a significant negative relationship on the respondents who watch anime, thus proving that watching anime does not have a negative impact on moral decay in the religious domain.

Analysis of the life domain showed that there was no significant relationship at all due to the larger alpha value at the $p>0.05$ level. The same goes for the reason domain that shows all 4 items are insignificant. While the property domain shows only 1 item that has a significant relationship to the frequency of watching anime while the other 6 items do not show a significant relationship. "Wastage (food/electricity etc.)" seen to have a significant negative correlation coefficient relationship. This explains that the frequency of watching anime has a negative relationship to wastage. The data proves that watching anime does not have a negative impact on waste. Thus, this study rejects the relationship of anime with the moral deterioration of adolescents which leads to the problem of social illness that occur today.

\section{DISCUSSION}

Based on the findings of the study above, it was found that anime has a weak relationship on only 3 items, namely 'deliberately do not fast in the month of Ramadhan, 'disobidience towards parents' and 'wastage'. All of the correlation relationships are in negative form indicating that anime has a good influence on all three negative items. While the majority of the 23 negative items of moral misconduct that lead to social disorders all show no significant relationship.

The data of this study is indeed surprising since most of the local community still has a bad perception of the anime watched by children and teenagers. Many studies have found a negative impact on anime when viewed excessively, but rather studies have also found that anime has a positive effect in some respects. For example, studies that found that anime had a negative effect were conducted by Wisdayuti [21]. While studies showing the positive effects of anime have been conducted by Roslina Mamat et.al [22], and Andini Arieska [23].

There are two factors why the data of this study were found to have a positive relationship to anime and rejecting the social ills stemming from anime. The first factor is that the 5anime series watched by the respondents are anime from the genres 'Kodomo' and 'Shounen' which are not excessive, lack negative elements and Contain positive elements which can be used as lessons. The second factor is due to the lack of frequency of respondents watching anime. The study data recorded only a majority of $56.5 \%$ of respondents watching anime at a frequency of 1 to 3 hours per week, while another $36.5 \%$ watched anime at a frequency of 3 to 5 hours, and only a small $7.1 \%$ of adolescents watched anime more than 5 hours per week. Thus, the negative elements found in the anime being watched do not have an effect on the adolescents themselves, instead there are positive elements that have a good effect on the adolescents being recorded, albeit a little bit. The results of the study will vary if the genre of the anime viewed has very high-frequency negative values, that the more anime the respondents watched, they are most likely to imitate the negative elements observed. Similarly, according to Zudin [24] study, the more negative elements are observed, the greater the influence on adolescents and the wrong decision of watching an anime of the wrong genre will also have a detrimental effect on adolescents.

\section{CONCLUSION}

These findings are preliminary findings on the association between anime exposure and its influence on adolescent attitudes. From the above findings, it can be concluded that the low level of anime exposure does not affect the behavior of adolescents who are exposed to anime watching. This may be due to the fact that the category of anime watched by teenagers is still in the kodomo and shounen anime groups (Detective Conan, Doraemon, Naruto, Crayon Shin Chan and One Piece) which contain least negative values.

In summary, this preliminary research dismissed all results of anime-related studies that had a negative impact on adolescents and also dismissed the prospect of anime causing moral deterioration of adolescents which contributes to social ills. However, this study only represents a small part of the sample of respondents involved in the pilot study. Findings may differ if larger samples and broader scope of location are involved. Anime should not be seen with a single negative perspective. The content of anime watched by adolescents should be scrutinized by parents and guardians by providing guidance and advice on the messages and lessons to be conveyed in an anime series. 
Therefore, further and following researches needs to be conducted to observe the anime's tendency towards attitudes, personalities, behaviours and social changes in adolescents, in accordance with the role of adolescents as the country's human capital of the future.

\section{REFERENCES}

[1] Harian Metro, 2015. "Statistik Moral Remaja Kita", https://www.hmetro.com.my/node/36116., Accessed 20 May 2016.

[2] Tamuri Ab Halim \& Zarin Ismail, 2005. "Hubungan media massa dengan pegangan nilai akhlak dan pengajaran pendidikan Islam", Kod penyelidikan GG003/2003. Fakulti Pendidikan, Universiti Kebangsaan Malaysia.

[3] Novianti N., 2007. Dampak Drama, Anime, dan Musik Jepang terhadap Minat Belajar Bahasa Jepang. Lingua Cultura, 1 (2), pp. 151-156.

[4] Hernita Noviarina, 2014. "Pengaruh Menonton Anime Terhadap Perilaku", https://www.academia.edu/6496305/Pengaruh_anime_t erhadap_perilaku. Accessed 5 April 2016

[5] Sameen Ahsan, 2014. "Wathing Anime Can Help Develop Child Psychology in Moral and Social Aspects", https://www.academia.edu/12134874/Watching_Anime _Can_Help_

[6] Eng, L., 2001. "The Politics of Otaku", http://www.cjas.org/ leng/otaku-p.htm.

[7] Gaylican, J.D., 2013. "Discrimination of Otaku culture in Japan and in the Philippines", http://janediannegaylican.blogsport.com/2013/04resear ch-paper-discrimination-of-otaku.html.

[8] Gravett. P., 2004. "Manga: Sixty Years of Japanese Comics", Harper Design.

[9] Roosfa Hashim, 2012. "Bentuk budaya asing dalam majalah dan komik remaja di pasaran tempatan", Jurnal Melayu (9)., pp. 85-98.

[10] Chambers, S., 2012, “Anime: From Cult Following to Pop Culture Phenomenon. The Elon Journal of Undergraduate Research in Communications, 3(2), 94107, retrieved from http://www.elon.edu/docs/eweb/academics/communicat ions/research/vol3no2/08ChambersEJFall12.pdf.

[11] Sallehuddin, I. S. \& Omar, F. I., 2011. "The perceived impact of anime on school children's aggressive behaviour", Retrieved from https://www.academia.edu/6448924

/THE_PERCEIVED_IMPACT_OF_ANIME_ON_SC HOOL_CHILDREN_S_AGGRESSIVE_BEHAVIOR.

[12] Jesus, F.D., 2014. Asian Persuasion: Whether Asian culture (specifically anime) affects western people's aesthetic views after adolescence. http://librarydb.saintpeters.edu:8080/bitstream/1234567 89/128/1/Francisco\%20De\%Jesus.pdf

[13] Rastati, R., 2015. Dari Soft Power Jepang Hingga Hijab Cosplay from Japanese Soft Power to Cosplay Hijab. Jurnal Masyarakat Dan Budaya, 17(3), Pp.371-388.

[14] Zainudin Sharif dan Norazmah Mohamad Roslan, 2011. "Faktor-faktor yang mempengaruhi remaja terlibat dalam masalah sosial di Sekolah Tunas Bakti, Sungai Lereh, Melaka", Journal of Education Psychology \& Counseling, 1(7), pp.115-140.

[15] Hutabalian, D.M., 2017. "Pengaruh Anime Naruto Terhadap Anak-Anak Sekolah Dasar Studi Kasus: Sd Swasta Antonius I Dan II, Kelas 1, 2, Dan 3", 2011, http://repository.usu.ac.id/handle/123456789/29755. Dilayari pada 20 Mac 2017.

[16] Zainal, K., Salleh, N.M., 2012. Case Study of Ethnic Behavior among Students in Urban and Rural Schools, International Journal of Knowledge, Culture and Change Management 11(3), pp. 161-170.

[17] F Idris, NRM Suradi, SS Muhamad, KA Mastor, H Kasan, K Zainal, 2012. Procedia-Social and Behavioral Sciences 59, 51-60.

[18] Azmi, A.M., Nik Hairi, O., Jamiah, M., Fauziah, I., Kartigavani, P., 2013. The involvement of teenagers in social problems at low cost housing areas, Social Sciences (Pakistan) 8(3), pp. 260-264.

[19] Tengku Elmi Azlina Tengku Muda, Nor 'Adha Abdul Hamid, Azizah Mat Rashid, Norul Huda Bakar, Norashikin Azmi, 2015. "Kesalahan Akhlak Dan Perkaitannya Dengan Faktor Kematangan, Kerohanian Dan Kesedaran Kendiri Individu", World Academic and Research Congress 2015 (World-AR 2015) Ar-Rahim Hall, YARSI University, Jakarta, Indonesia,

[20] Sohana Abdul Hamid, 2016. "Pengaruh Media Massa Terhadap Perubahan Sosial Masyarakat", Jurnal EBangi, Special Issue 1, pp. 214-226

[21] Wisdayuti Purbani, 2012. "Membaca Komik Crayon Shinchan Dengan Wacana Posmodernisme", Diksi, 13(1).

[22] Abdullah Sulong, 2010. "Pengaruh Media Elektronik Terhadap Keruntuhan Akhlak Pelajar", UTM, pp. 1-9.

[23] Roslina Mamat, Roswati Abdul Rashid, Normaliza Abdul Rahim \& Hazlina Abdul Halim, 2014. "Imej Karakter Animasi Jepun (Anime) dalam Kalangan Remaja di Selangor", Sains Humanika, 67(1).

[24] Andini Arieska, 2016. "Pengaruh Tayangan Kekerasan dalam Serial Kartun Naruto Terhadap Pembentukan Karakter Anak Usia 9-12 Tahun di Kelurahan Rappang Kecamatan Panca Rijang Kabupaten Sidrap", Tesis Ijazah Sarjana, Universitas Islam Negeri Alauddin Makassar. 